\title{
Modernisasi Alat Pertanian di Cikoro Gowa 2005-2015
}

\author{
Nurwahyuningsih ${ }^{1}$, Ahmadin $^{2}$, Asmunandar $^{3}$ \\ Program Studi Pendidikan Sejarah Fakultas Ilmu Sosial UNM \\ Email: nurwahyuningsih226@gmail.com
}

\begin{abstract}
Abstrak
Penelitian ini bertujuan untuk mengetahui kehidupan masyarakat tani sebelum masuknya alat modernisasi pertanian di Cikoro Kabupaten Gowa, Perkembangan pertanian setelah adanya alat modernisasi, serta dampak dari alat modernisasi pertanian bagi kehidupan masyarakat tani pada bidang sosial-budaya dan ekonomi di Cikoro Kabupaten Gowa (2005-2015). Penelitian ini merupakan penelitian yang bersifat deskriptif-analisis dengan menggunakan metode penelitian sejarah melalui tahap heuristik, kritik, interpretasi dan historiografi.. Hasil penelitian ini menunjukan bahwa sebelum masuknya alat teknologi modern dalam bidang pertanian di Kelurahan Cikoro, pertanian masih bersifat subsisten, dimana masyarakat hanya berproduksi untuk kebutuhan pribadi dan memenuhi kebutuhan keluarga. Kemudian dengan masuknya alat modernisasi pertanian, kehidupan masyarakat tani di Kelurahan Cikoro mulai mengalami peningkatan terutama dari segi ekonominya. Selain itu juga memberi dampak terhadap sistem mata pencaharian masyarakat setempat. Dari penelitian ini dapat ditarik kesimpulan bahwa pertanian dengan menggunakan alat-alat teknologi modern lebih efektif dari penggunaan alatalat tradisional di era serba modern sekarang ini. Disamping itu, juga karena penggunaannya yang tidak terlalu banyak memakan waktu.
\end{abstract}

\section{Kata kunci : Modernisasi, Alat dan Pertanian}

\begin{abstract}
This study aims to find out the life of the peasant community before the entry of agricultural modernization tools in Cikoro, Gowa Regency, agricultural development after the modernization tool, as well as the impact of agricultural modernization tools for the life of farming communities in the socio-cultural and economic fields in Cikoro, Gowa Regency (2005-2015). This research is a descriptive analysis using historical research methods through heuristics, criticism, interpretation and historiography. The results of this study indicate that before the inclusion of modern technological tools in agriculture in Cikoro Village, agriculture was still subsistence, where the community only produced for personal needs and fulfilled family needs. Then with the inclusion of agricultural modernization tools, the life of the farming community in Cikoro Village began to experience an increase, especially in terms of its economy. Besides that it also has an impact on the livelihood system of the local community. From this study it can be concluded that agriculture using modern technological tools is more effective than the use of traditional tools in today's modern era. Besides that, also because its use is not too time consuming.
\end{abstract}

Keywords: Modernization, Tools and Agriculture 


\section{A. Pendahuluan}

Pertanian merupakan roda penggerak ekonomi nasional. Sektor pertanian memegang peranan penting dari keseluruhan perekonomian nasional. Keberadaan sektor pertanian telah memberikan kontribusi yang besar untuk pemerintah maupun masyarakat. (Indonesia, 1983).

Salah satu upaya dalam meningkatkan produksi pertanian adalah dengan dilakukannya pengembangan pada sektor pertanian. Pengembangan sektor pertanian sendiri merupakan salah satu strategi kunci dalam memacu pertumbuhan ekonomi pada masa yang akan datang.

Pembangunan pertanian pada dasarnya adalah suatu proses perubahan pada berbagai aspek di bidang pertanian. Perubahan tersebut tidak hanya berdampak pada mekanisme dan teknologi namun juga berdampak pada sistem sosial budaya. Dalam bidang pertanian, perubahanperubahan sosial budaya petani akibat dari modernisasi adalah dengan diperkenalkannya mesin-mesin, seperti pemakaian traktor tangan dan mesin perontok padi. Modernisme kemudian muncul dalam semangat masyarakat yang mengandalkan industri dan mekanisasi, dimana mesin menjadi kunci utama (Aziz, 2004).

Seiring dengan berjalannya waktu, perkembangan teknologi tak terbendung lagi, peranan teknologi kian hari semakin dibutuhkan, dengan hadirnya teknologi justru menghidupkan pertumbuhan ekonomi yang cukup memuaskan seperti mempertinggi efisiensi tenaga manusia dan juga dapat meningkatkan taraf hidup petani. (Mulyoto, 2000)

Modernisasi yang terjadi di tengahtengah masyarakat saat ini khususnya masyarakat di Kelurahan Cikoro tidak terlepas dari kebutuhan masyarakat yang kian hari kian meningkat dan kian bertambah banyak. Masyarakat di daerah ini pada umumnya dalam mengerjakan berbagai usaha dalam bidang pertanian masih bersifat sederhana. Masyarakat petani juga masih memerlukan tenaga manusia, dalam artian bahwa dalam kehidupan bermasyarakat, petani di Kelurahan Cikoro masih tetap membutuhkan bantuan tenaga manusia yang pada dasarmya merupakan adat gotong royong masyarakat setempat, mulai dari penanaman bibit hingga waktu panen berlangsung.

Adapun urgensi dari penelitian ini selain sebagai salah satu acuan dalam menambah khasanah pengetahuan terkait sejarah sosial dalam kehidupan bermasyarakat khusunya di Kelurahan Cikoro, juga dimaksudkan untuk menjadi tolak ukur dalam memahami perubahanperubahan sosial yang terjadi dalam masyarakat terutama masyarakat tani.

Disamping itu untuk menyelesaikan penulisan dalam penelitian ini dilakukan tinjauan pustaka atau mencari dan menemukan kajian yang relevan. Kajian relevan dalam suatu karya ilmiah perlu untuk ditelusuri guna mencari tahu apakah ide pokok suatu kajian sudah diangkat oleh penulis lain atau belum. Penelitian ini berusaha untuk mengaji mengenai modernisasi alat pertanian di Cikoro Kabupaten Gowa.

Kajian relevan berupa buku ditemukan dalam bentuk buku, yang telah diterbitkan oleh beberapa orang penulis. Adapun kajian mengenai modernisasi alat petanian dalam bentuk buku yang telah terbit pada umumnya membahas modernisasi pertanian secara keseluruhan. Tanpa secara spesifik membahas mengenai modernisasi alat pertanian yang sampai sekarang masih berlangsung sebagai salah satu bentuk peningkatan kemajuan dalam bertani khususnya pada lahan persawahan di Cikoro Kaupaten Gowa.

Buku-buku yang terkait dengan modernisasi alat pertanian tersebut diantaranya yaitu buku yang berjudul Pertanian Masa Depan "Pengantar Untuk Pertanian Berkelanjutan dengan Input Luar Rendah yang ditulis oleh Coen Reijntjes Dkk, buku ini memberikan gambaran terkait perkembangan pertanian masa 
depan dengan perimbangan-pertimbangan yang terjadi sebelumya. Selain itu juga terdapat buku yang ditulis oleh Bustanul Arifin berjudul Spektrum kebijakan pertanian indonesia: telaah struktur, kasus dan alternatif strategi, yang banyak membahas tentang pertanian, perkembangan, sebab, dampak dan akibatnya dalam kehidupan masyarakat. Juga buku dengan judul Pengembangan Masyarakat Wacana dan Praktik yang ditulis oleh Zubaedi tahun 2013, merupakan sumber untuk memahami bagaimana pola orientasi pengembangan masyarakat di era modern serta kehidupan sosial-ekonomi petani.

Selain buku-buku yang membahas secara khusus mengenai pertanian tersebut, digunakan pula buku-buku penunjang lain yang masih relevan dengan tema penelitian. Selain buku juga digunakan beberapa jurnal yang terkait dengan modernisasi alat pertanian, diantaranya Jurnal Modernisasi Pertanian (Studi Kasus Tentang Peluang Kerja Dan Pendapatan Petani Dalam Sistem Pertanian Di Desa Dukuhdempok Kecamatan Wuluhan Kabupaten Jember) milik Bayu Enggal Rifkian, Pudjo Suharso, Sukidin ditulis pada tahun 2017 yang fokus pembahasannya terkait tentang peluang kerja bagi para petani baik petani pemilik maupun buru tani serta pendapatan petani di desa Dukuh dempok Kecamatan Wuluhan Kabupaten Jember.

Selain jurnal, juga digunakan skripsi sebagai kajian relevan dalam penelitian ini, yaitu Skripsi yang ditulis oleh Idris tahun 2004 dengan judul Modernisasi Pertanian di Desa Lengkese Kec.Mangngarabombang Kab. Takalar (1982-1998). Dalam pembahasan skripsi ini, difokuskan pada bagaimana keberlangsugan hidup masyarakat di Desal lengkese sebelum dan setelah modernisasi.

\section{B. Metode Penelitian}

Penelitian ini merupakan penelitian sejarah yang bersifat deskriptif analisis dengan tujuan untuk menemukan dan mendeskripsikan secara analitis serta menginterpretasikan terkait modernisasi alat pertanian di Kelurahan Cikoro Kecamatan Tompobulu Kabupaten Gowa.

Dalam suatu penulisan karya ilmiah, terdapat cara yang digunakan untuk menyusun karya ilmiah tersebut. Hal ini sering disebut sebagai metode. Menurut Kenneth D. Bailey, metode adalah teknik penelitian atau alat yang dipergunakan untuk mengumpulkan data. (Madjid, 2008) Berdasarkan uraian tersebut di atas dapat disimpulkan bahwa metode sejarah merupakan cara atau tehnik dalam merekontruksi peristiwa masa lampau, melalui empat tahapan kerja yaitu heuristik, kritik, interpretasi, dan historigrafi.

\section{Heuristik}

Heuristik merupakan tahap awal dalam penelitian sejarah, yaitu mencari dan mengumpulkan sumber-sumber atau data yang berhubungan dengan topik yang akan diteliti. (Sjamsuddin, 2012). Dalam tahap pengumpulan data ini akan banyak menyita waktu, biaya, tenaga serta pikiran, karena peneliti diwajibkan mencari sumber-sumber terkait penelitian yang dilakukan.

Pada tahap heuristik ini seorang peneliti mencari dan mengupayakan penemuan atas sumber sejarah yang memilki keterkaitan dengan objek penelitian. Heuristik juga diartikan mencari dan mengumpulkan sumber-sumber sejarah yang terkait dengan topik penelitian untuk mendapatkan sumber yang akurat. Dapat juga diartikan sebagai kegiatan penghimpunan jejak-jejak masa lampau, yakni peninggalan sejarah atau sumber apa saja yang dijadikan informasi dalam pengertian studi sejarah. Dalam melakukan pengumpulan sumber, peneliti menempuh dua cara:

\section{a. Penelitian Lapangan}

Kegiatan yang dilakukan dalam penelitian lapangan adalah mengadakan pegumpulan data secara langsung terhadap obyek yang menjadi sasaran penelitian. Dalam hal ini peneliti menggunakan kegiatan observasi dan metode wawancara. Kegiatan tersebut dijelaskan sebagai berikut 1) Observasi 
Observasi adalah pengamatan secara langsung terhadap objek yang akan diteliti atau terhadap lokasi penelitian. Metode observasi yang peneliti maksud adalah mengadakan pengamatan langsung terhadap masyarakat atau objek penelitian. Dalam hal ini peneliti melakukan observasi pada lokasi penelitian yaitu di Kelurahan Cikoro Kecamatan Tompobulu Kabupaten Gowa yang terkait dengan modernisasi alat pertanian, dimana peneliti mendatangi lokasi penelitian untuk melakukan peninjauan langsung terhadap objek yang akan diteliti.

\section{2) Wawancara}

Peneliti melakukan wawancara terhadap orang yang dianggap berkompeten dalam objek yang diteliti. Wawancara tersebut dilakukan terhadap para warga yang berprofesi sebagai petani seperti pemilik lahan dan buru tani maupun pemerintah setempat. Hasil wawancara kemudian dapat direkam dan atau dicatat untuk selanjutnya diperbaiki pada saat penyusunan laporan penelitian. Selain itu, peneliti juga menggunakan dokumentasi penelitian. Hal tersebut dilakukan agar data yang diperoleh peneliti sifatnya objektif dan dapat dipertanggungjawabkan.

\section{3) Penelitian Pustaka}

Studi pustaka merupakan salah satu langkah penting dalam penelitian sejarah. Dalam studi pustaka ini dilakukan studi terhadap sejumlah bahan pustaka, baik yang berupa buku, dan hasil penelitian lainnya yang memiliki kaitan dengan topik penelitian. Penelitian pustaka dilakukan untuk menunjang penelitian lapangan. Penelitian pustaka dapat dilakukan dengan mengumpulkan sumber berupa buku-buku, dokumen pemerintah setempat, hasil penelitian maupun artikel ilmiah yang berkaitan dengan modernisasi pertanian. adapun tempat untuk mendapatkan sumber tersebut diperoleh dari perpustakaan wilayah provinsi Sulawesi selatan, perpustakaan umum Universitas Negeri Makassar, perpustakaan jurusan pendidikan sejarah Universitas Negeri Makassar, Kantor Kecamatan Tompobulu,
Kantor Kelurahan Cikoro, internet dan toko buku.

\section{Kritik}

Jika sumber-sumber yang digunakan sudah dianggap cukup, langkah selanjutnya adalah menilai sumber tersebut untuk menyeleksi dan menguji kebenaran dan keabsahan suatu sumber, guna mendapatkan data yang otentik. Dalam kritik sumber, terdapat penekanan tertentu yang bertujuan untuk memberikan definisi kritik sumber itu sendiri. Tujuan dari kegiatan ini adalah bahwa setelah peneliti berhasil mengumpulkan sumber-sumber dalam penelitiannya, ia tidak akan menerima begitu saja apa yang tercantum dan tertulis pada sumber-sumber itu. Selanjutnya ia harus menyaringnya secara kritis agar terjaring fakta yang menjadi pilihannya. Langkah-langkah inilah yang disebut kritik sumber, baik terhadap bahan materi (ekstern) maupun terhadap subtansi (isi) sumber. (Sjamsuddin, 2012)

\section{Interpretasi}

Pada tahap ini dilakukan penafsiran terhadap data-data yang telah diseleksi. Kemampuan interpretasi adalah menguraikan fakta-fakta menurut data temuan karena tidak ada masa lalu dalam konteks sejarah yang sifatnya aktual sehingga harus ditafsirkan melalui data-data tersebut. Sumber atau data yang telah diseleksi dapat digunakan sebagai sumber atau bahan penulisan, namun dengan adanya sumber tersebut juga masih harus dilakukan penelitian lebih lanjut yang dikenal dengan interpretasi (penafsiran). Dalam tahap ini peneliti dituntut untuk bisa menghasilkan interpretasi yang tidak memihak dan sesuai dengan keberadaan fakta yang ada karena unsur subjektivitas terkadang dapat mempengaruhi isi penulisan. Hal ini dimaksud untuk memberi arti terhadap aspek yang diteliti, mengaitkan fakta yang satu dengan fakta lainnya agar ditemukan kesimpulan penulisan ilmiah.

\section{Historiografi}

Tahap ini merupakan tahap terakhir dalam penulisan sejarah. Pada tahap ini 
peneliti akan menuliskan peristiwa sejarah tersebut dalam sebuah tulisan yang dalam penulisan, pemaparan dan pelaporan menggunakan tata cara tertentu. Dimana dalam hal ini, penelitian yang peneliti lakukan adalah penelitian dengan kajian kepustakaan dan lapangan. Penulisan sejarah merupakan proses penjelasan dari semua kegiatan dalam proses penelitian sejarah. Pada tahap ini peneliti mencoba untuk menggambarkan hasil penelitiannya. Dalam hal ini pada penelitian tentang modernisasi pertanian, Peneliti mencoba untuk memberi gambara kehidupan masyarakat tani sebelum modernisasi, pertanian setelah modernisasi serta dampak modernisasi pertanian terhadap kelangsungan hidup masyarakat di Cikoro Kabupaten Gowa.

\section{Pembahasan}

1. Pertanian Setelah Modernisasi Di Cikoro Kabupaten Gowa

\section{a. Adopsi Teknologi Modern}

Dalam proses adopsi bentuk-bentuk teknologi dalam pertanian, tentu masyarakat mengadakan suatu bentuk penyuluhan. Penyuluhan dapat berperan dalam proses pembangunan masyarakat dalam bentuk usaha dengan menopang dua sisi yang saling berkepentingan yaitu pada masyarakat desa yang bersangkutan di satu pihak dan pemerintah di pihak lain.

Peranan penyuluhan juga dapat dilihat dari peranannya sebagai penerima ide, inspirasi, dan aspirasi yang timbul secara murni dari masyarakat dan dapat menyampaikan secara tepat melalui jalur penyuluhan kepada segenap pihak yang berkepentingan dengan pembangunan masyarakat desa. Dalam proses pembangunan, desa mempunyai berbagai masalah dan kepentingan yang menyangkut hajat hidup orang banyak yang perlu dipahami oleh masyarakat itu sendiri dan para pengambil keputusan dan perencana.

Namun berdasarkan wawancara dengan salah satu masyarakat setempat bahwa mereka mengadopsi mesin pertanian ini bukan karena melalui bentuk penyuluhan dari pemerintah melainkan karena adanya kesadaran masyarakat setempat untuk meningkatkan kesejahteraan keluarga mereka. Seperti salah satu wawancara yang telah di ungkapkan oleh masyarakat setempat bahwa adanya mesin ini bukan karena diberitahukan oleh orang lain atau saudara-saudara kami atau dari bentukbentuk penyuluhan pemerintahan apapun melainkan mereka menginginkan menggunakan mesin pertanian ini karena keinginan masyarakat petani itu sendiri walaupun mesin ini hanya dapat mereka sewa tiap kali mengolah lahan pertanian mereka. (Rappung, 2019)

\section{b. Proses Modernisasi Pertanian}

Terminologi modernisasi pada berbagai aspek kehidupan manusia, secara fundamental sangat kompleks dan tidaklah sesederhana seperti yang dipahami secara sempit oleh sementara orang. Modernisasi tidak hanya mencakup perubahan secara fungsional atau sistem (teknik) dari caracara tradisional ke modern, tetapi juga mengarah pada perubahan pola pikir manusia. (Ahmadin, 2009).

Modernisasi di bidang pertanian di Indonesia di tandai dengan perubahan yang mendasar pada pola-pola pertanian, dari cara-cara tradisional menjadi cara-cara yang lebih maju. Perubahan-perubahan tersebut meliputi beberapa hal, antara lain dalam pengelolahan tanah, penggunaan bibit unggul, penggunaan pupuk, pengunaan sarana-sarana produksi pertanian, dan pengaturan waktu panen.

Dalam bidang pertanian, perubahanperubahan sosial petani akibat dari modernisasi adalah dengan diperkenalkannya mesin-mesin, seperti mesin penuai dan traktor tangan telah menghilangkan mata pencaharian penduduk yang selama ini mendapatkan upah dari menuai. Kemudian, pemakaian traktor tangan telah menggantikan tenaga hewan seperti sapi, kerbau maupun kuda, sehingga sebagaian besar petani tidak lagi berternak kerbau. (Munthe, 2007)

Untuk melaksanakan modernisasi pertanian di suatu wilayah diperlukan 
penyediaan bahan dan alat-alat produksi yang dapat dijangkau petani. Ilmu dan teknologi pertanian senantiasa meningkat, pasaran untuk setiap jenis hasil usaha tani yang dapat merangsang produksi, serta tersedianya alat pengangkutan yang baik dan ekonomis.

Kelurahan Cikoro sendiri merupakan salah satu daerah pertanian yang terlambat menggunakan alat pertanian yang modern padahal di pulau jawa sudah mulai ada sejak sekitar tahun 1960.an, sedangkan untuk Kelurahan Cikoro penggunaan alat modern baru dimulai pada tahun 2005 dengan adanya mesin penuai/perontok padi yang lebih dikenal dengan deros di daerah setempat.

Setelah masuknya alat modernisasi diharapkan petani di Kelurahan Cikoro dapat bersifat dinamis, produktif ekonomis, mau dan mampu menggunakan cara-cara baru dalam setiap kegiatan usaha taninya. Mengadakan usaha tani yang bersifat konsumtif, produktif serta pemanfaatan sumber daya alam terutama tanah dengan lebih produktif dan efisien. Dengan adanya modernisasi berarti pula mengisi dan meletakkan dasar yang lebih kuat bagi perkembangan dan pertumbuhan ekonomi regional dan nasional yang sehat, serta sebagai dasar untuk pembangunan tahap selanjutnya.

Namun demikian, khusunya di dalam mewujudkan tujuan-tujuan yang ingin dicapai, maka modernisasi pertanian tentunya akan membutuhkan beberapa prasyarat yang mutlak harus diperhatikan urgensinya, paling tidak dalam mengembangkan areal dan mekanisme pertanian, kehadiran alat-alat dan mesinmesin pertanian, teknik tanah dan air, bangunan pertanian elektrifikasi pertanian, mesin-mesin pengolahan hasil pertanian dan masalah teknisi perbaikan alat modern tersebut.

Sebelum adanya modernisasi alat pertanian, masyarakat masih bersifat tradisional dimana masyarakat petani menggunakan berbagai alat untuk mengolah lahan sawah mereka.
Pengetahuan masyarakat tani di Cikoro tentang sistem pertanian yang tradisional, mereka dapatkan secara turun temurun sehingga kebiasaan itu telah diwariskan dari generasi ke generasi dalam melaksanakannya sebagai petani. Keyataan itu dapat dilihat dari kebiasaan masyarakat petani yang ada di Cikoro menggunakan alat tradisional untuk membantu mengelolah lahan sawah mereka, salah satunya dengan menggunakan alat yang umumnya dipakai untuk mengolah tanah yaitu cangkul, dalam menggunakan alat tradisional ini membutuhkan beberapa personil untuk mengelolah dengan alat ini.

Namun seiring berjalannya waktu mesin teknologi pertanian masuk ke Cikoro dan mulai mengubah sistem pertanian dengan alat yang modern seperti masuknya traktor tangan dan pemakaian alat tradisional itupun mulai berkurang, diterapkannya modernisasi teknologi pertanian diharapkan dapat merangsang masyarakat untuk membuat lebih baik, guna meningkatkan pendapatan mereka. Bagi petani di Cikoro secara umum sudah beralih pada jenis dan sistem penggunaan peralatan modern dari tradisional.

\section{1) Alat Pertanian Tradisional}

Sebelum memasuki tahun 2005 atau sebelum masuknya sentuhan teknologi di Cikoro ada berbagai macam penggunaan alat-alat (alat tradisional) yang umumnya digunakan oleh masyarakat tani yang ada di Cikoro sebagai berikut:

\section{a) Nangkala}

Merupakan salah satu alat tradisional yang digunakan masyarakat tani untuk meratakan lahan sawah, alat yang digunakan oleh masyarakat di Cikoro dalam mengelolah lahan persawahan dimana cara kerja alat ini yaitu selain membutuhkan tenaga kerja manusia untuk menggerakannya juga di butuhkan tenaga hewan seperti kerbau atau sapi untuk mengoperasikannya.

Walaupun masyarakat di Cikoro tidak menggunakan alat modern alat ini juga dapat digunakan untuk meratakan lahan yang kemudian lahan tersebut siap untuk di 
tanami, alat ini terbuat dari papan yang lebar dimana ujung yang satu melengkung ke atas agar pada saat alat tersebut di dorong ujungnya tidak masuk ke dalam lumpur, dan ujung yang satunya menyerupai kaki bangku yang agak panjang, kira-kira setinggi perut orang dewasa, guna sebagai pegangan untuk mendorong alat tersebut.

\section{b) Bingkung (Cangkul)}

Adalah alat yang paling umum digunakan oleh petani-petani di Cikoro dalam mengolah lahan sawah maupun ladang, dan bahkan alat ini masih digunakan sebagai alat pertanian walaupun mesin-mesin pertanian sudah mampu hadir di dalam kehidupan masyarakat petani di Cikoro. Karena kebutuhan akan alat ini tidak hanya pada proses pengolahan lahan persawahan tetapi juga digunakan untuk lahan perkebunan.

Menurut salah satu masyarakat setempat bahwa tidak mutlak mereka hanya menggunakan traktor saja dalam mengolah lahan persawahan, tetapi juga membutuhkan alat seperti cangkul dalam mengolah lahan persawahan sesudah menggunakan traktor. Disamping pengolahan lahan dibutuhkan juga tenaga kerja yang dimaksud dengan tenaga kerja disini adalah tenaga kerja manusia bukan mesin, dan untuk penetapan biaya standarnya pertama-tama harus menetapkan berapa jumlah jam kerja yang dapat diselesaikan oleh tenaga kerja itu yang harus ditempuhnya dalam produksi.

\section{2) Alat Pertanian Modern}

\section{a) Traktor}

Merupakan jenis peralatan mekanis yang digunakan untuk mengelolah lahan persawahan. Jenis alat ini tentunya terbuat dari besi yang sistem operasinya digerakkan/ditarik oleh tenaga mesin dibawah kendali tenaga manusia. Alat bajak ini dioperasikan pada tahap permulaan mengolah lahan sawah, karena lahan yang telah ditanami padi telah menjadi lahan keras sehingga membutuhkan alat bajak untuk membongkar kembali lahan padat tersebut.
Adapun alat dan sistem bajak areal persawahan yang mengalami perubahan, dimana intinya terletak pada bahan pembuatan alat bajak serta motor penggeraknya. Peggunaan alat tersebut setelah menggunakan cangkul sebagai alat pengolah lahan yang tidak menggunakan mesin modern sebagai alat bajak masyarakat yang ada di Kelurahan Cikoro dan jumlah dalam mengelolah lahan persawahan dengan menggunakan alat ini lebih dari dua orang.

Mekanisasi pertanian merupakan teknologi yang lebih tinggi tingkatannya dari teknologi tradisional. Hal ini bertujuan untuk meningkatkan produktivitas dan pendapatan petani atau masyarakat tani pada khususnya. Namun penggunaan mesin-mesin pertanian harus ditunjang oleh teknologi lainnyan yaitu panca usaha tani, serta penggunaannya harus tepat.

Adapun hambatan sekaligus kelemahan terhadap mekanisasi ini termasuk terbatasnya peralatan, bahan bakar, modal, keterampilan, fasilitas perawatan dan suku cadangnya serta kondisi ekologi yang sulit sehingga peralatan cepat menjadi usang dan beresiko tinggi menjadi rusak. Bergantung pada situasi dan ekologi lokal, mekanisasi dengan menggunkan bahan bakar minyak bisa lebih atau kurang menarik bagi petani perorangan.

\section{b) Pemupukan}

Merupakan bahan yang diberikan ke dalam tanah baik yang organik maupun yang anorganik dengan maksud untuk mengganti kehilangan unsur hara dari dalam tanah dan bertujuan untuk meningkatkan produksi tanaman dalam faktor lingkungan yang baik. Di daerah tropis terutama bagi yang penduduknya melakukan usaha dibidang pertanian, pupuk anrganik sangat dikenal dan disukai, hal ini dikarenakan:

(1) Selain karena pupuk alam keadaan dan jumlahnya kurang dapat mencukupi kebutuhan, juga karena pupuk buatan sangat praktis dalam pemakaian, artinya pemakaian dapat disesuaikan dengan perhitungan hasil penyelidikan akan 
difisiensi unsur hara yang tersedia dalam kandungan tanah.

(2) Penyediaan pupuk anorganik bagi para pemakainya dapat meringankan ongkos-ongkos angkutan, mudah didapat, dapat disimpan lama, dan konsentrasinya akan zat-zat makanan bagi pertumbuhan akan perkembangan tanaman ternyata tinggi.

Adanya pemakaian berbagai macam pupuk, yang menurut salah satu wawancara dilokasi, mereka memperolehnya dari pasar terdekat berdasarkan rekomendasi dari Dinas Pertanian daerah Gowa. Jenis pupuk yang digunakan oleh masyarakat petani di Cikoro adalah Urea, TSP, ZA dan juga Kcl. (Bora', 2019 )

\section{c) Deros (Mesin penggiling padi)}

Adalah alat yang digunakan untuk memisahkan bulir-bulir padi dari tangkainya. Dimasa yang serba modern ini, ada begitu banyak mesin yang bermanfaat untuk membantu perkerjaan manusia salah satunya adalah mesin oenggiling padi ini. Mesin ini masuk di Kelurahan Cikoro pada tahun 2005 dimana tahun tersebut merupakan awal masuknya modernisasi alat pertanian di Cikoro kabupaten Gowa.

\section{d) Bibit Unggul}

Benih atau bibit adalah simbol dari suatu permulaan, benih merupakan inti dari kehidupan alam semesta dan yang paling penting adalah kegunaannya sebagai penyambung dari kehidupan tanaman. (Lita, 2004). Benih bermutu ialah benih yang telah dinyatakan sebagai benih yang berkualitas tinggi dari jenis tanaman unggul. Benih berkualitas itu memiliki daya tumbuh lebih dari 99\% dengan ketentuan sebagai berikut:

(1) Memiliki viabilitas atau dapat mempertahankan kelangsungan pertumbuhannya menjadi tanman yang baik atau mampu berkecambah.

(2) Memiliki kemurnian, artinya terbebas dari kotoran, terbebas dari benih jenis tanaman lain dan bebas pula dari hama dan penyakit. (Ance, 2003)

\section{c. Jarak Sosial dan Pola Hubungan Kerja}

Dalam perspektif sosiologi manusia dipandang sebagai makhluk sosial yang selalu membutuhan orang lain. Sejak manusia dilahirkan ke dunia ini, sadar atau tidak sesungguhnya ia telah belajar dan berkenalan dengan hubungan-hubungan sosial yakni hubungan antar manusia dalam masyarakat.

Untuk mengetahui secara mendalam tentang jarak sosial dan pola hubungan kerja, maka terlebih dahulu perlu digambarkan tentang karakteristik petani sekaligus mengetahui bahwa perbedaan status turut menentukan. Dalam kehidupan bermasyarakat senantiasa terjadi perbedaan status antara satu dengan yang lain, baik secara individu maupun dalam kelompok.

Dalam kehidupan bermasyarakat di Kelurahan Cikoro sendiri, sistem pelapisan sosial tidak terlalu nampak. Hal ini dapat dilihat dari bagaimana masyarakat dapat saling berbaur dalam berbagai aktivitas termasuk di dalamnya adalah ketika tiba masa untuk turun ke sawah tatkala waktu membajak telah tiba.

\section{d. Sistem Bagi Hasil}

Bagi hasil merupakan suatu bentuk kerja sama antara pemilik lahan atau modal dengan pekerja. Secara sederhana dapat dikemukakan bahwa yang dimaksud dengan sistem bagi hasil adalah perjanjian pengolahan tanah, dengan upah sebagian dari hasil yang diperoleh dari pengolahan tanah itu. (Lubis, 1996).

Ahli lain memberikan definisi bahwa yang dimaksud dengan sistem bagi hasil disebutnya mudarabah, yaitu satu pihak menyediakan modal dan pihak lain memanfaatkannya untuk tujuan-tujuan usaha, berdasarkan kesepakatan bahwa keuntungan dari usaha tersebut akan dibagi menurut bagian yang ditentukan. (Darwis, 2016)

Munculnya perjanjian ini dikarenakan adanya petani pemilik lahan yang tidak memiliki keahlian dalam bercocok tanam atau tidak memiliki kesempatan untuk mengelola suatu jenis pertanian tersebut, dan terkadang juga perjanjian itu muncul karena adanya pekerja atau penggarap yang 
memiliki keahlian dalam mengelola suatu jenis usaha pertanian, namun tidak memiliki lahan atau modal untuk bercocok tanam. Oleh karena itu, petani melakukan suatu perjanjian bagi hasil, selain untuk mencari keuntungan antara kedua belah pihak juga untuk saling mempererat tali persaudaraan dan tolong- menolong diantara mereka. Perjanjian bagi hasil yang dilakukan oleh masyarakat pedesaan pada umumnya adalah atas kemauan bersama (pemilik lahan dan penggarap), dengan tujuan saling tolong-menolong antara petani, dan perjanjian bagi hasil tanah pertanian yang berlaku didalam masyarakat umumnya, dilakukan secara lisan dan atas dasar saling percaya kepada sesama anggota masyarakat. (Parlindungan, 1991)

Demikian juga perjanjian bagi hasil yang terjadi di Kelurahan Cikoro Kecamatan Tompobulu Kabupaten Gowa yang pada umumnya dilakukan secara lisan dan hanya berdasar atas rasa saling percaya kepada sesama masyarakat. Adapun sistem bagi hasil yang dilakukan masyarakat di Cikoro pada dasarnya tergantung dari kesepakatan bersama menurut adat kebiasaan setempat yang berlaku secara turun-temurun. Intinya mereka hanya menganut sistem bagi hasil yang telah berlaku pada masyarakat umumnya berdasarkan perjanjian yang telah disepakati bersama.

\section{Kesimpulan}

Berdasarkan uraian pembahasan yang telah dipaparkan pada halaman-halaman sebelumnya, maka kesimpulan yang dapat diangkat sebagai berikut.

Kehidupan masyarakat tani sebelum adanya modernisasi di Cikoro masih bersifat subsistem, serta penggunaan alatalat pertanian yang masih tradisional.

Tahun 2005 mesin Penrontok padi masuk di Kelurahan Cikoro, yang kemudian menjadi latar belakang masuknya mesin teknologi pertanian Cikoro Kabupaten Gowa.

Masuknya teknologi pertanian, merupakan salah satu keinginan, dalam kehidupan ekonomi keluarga petani.
Dalam penerapan modernisasi alat pertanian di Cikoro Kabupaten Gowa membawa dampak sosial budaya seperti dampak terhadap tenaga kerja, dan dampak terhadap hubungan kekerabatan.(Junaedah and Amirullah, 2018) Dibidang ekonomi, berdampak pada mata pencaharian, dan pendapatan masyarakat petani.

\section{DAFTAR PUSTAKA}

Ahmadin, 2013. Metode Penelitian Sosial. Makassar: Rayhan Intermedia.

Ahmadin, 2009. Ketika Lautku Tak Berikan Lagi. Makassar: Rayhan Intermedia.

Ance, 2003. Teknologi Benih Pengolahan Dengan Cara-cara Yang Semestinya. Jakarta: Rineka Cipta.

Aziz, A., 2004. Toraja Simbolisme Unsur Visual Rumah Tradisional. Yogyakarta: Ombak.

Bora', 2019 . Wawancara [Interview] (6 Maret 2019).

Darwis, R., 2016. Sistem Bagi Hasil Pertanian Pada Masyarakat Petani Penggarap Di Kabupaten Gorontalo Perspektif Hukum Ekonomi Islam. minggu November.p. 9.

Indonesia, P. E. P., 1983. Petumbuhan dan Pemeraaan dalam Pembangunan Pertanian. jakarta: Perhepi.

Lita, 2004. Teknologi Benih. Jakarta: Grafindo Persada.

Lubis, C. P. d. S. K., 1996. Hukum Perjanjian Dalam Islam. Jakarta: Sinar Grafika.

Madjid, A. R. H. d. M. S., 2008. Pengantar Ilmu Sejarah. Ujung Pandang: Rayhan Intermedia.

Mulyoto, d., 2000. Mesin-mesin Pertanian. Jakarta: Bumi Aksara.

Munthe, H. M., 2007. Modernisasi Dan Perubahan Sosial Masyarakat Dalam Pembangunan Pertanian: Suatu Tinjauan Sosiologis. Jurnal Harmoni Sosial, p. 2.

Parlindungan, A., 1991. Undang-Undang Bagi Hasil di Indonesia. Mandar Maju: Bandung 
Junaedah, S. and Amirullah (2018) 'Gang

Action and Shifting Patterns of Patron-

Client Relations in Southeast Gowa

1958-1961', atlantis-press., 226(Icss),

pp. 1033-1038. doi:

https://doi.org/10.2991/icss-

18.2018.216.

Rappung, 2019. Wawancara [Interview] (5 maret 2019).

Sjamsuddin, H., 2012. Metodologi Sejarah. Yogyakarta: Ombak.

Sjamsuddin, H., 2012. Metodologi Sejarah.

Yogyakarta: Ombak. 